\title{
Microfilming Services of Large University and Research Libraries in the United States
}

\section{Dr. Muller is assistant director of librar-} ies, University of Michigan.

TN CONnEction with a study of micro1 filming services at the University of Michigan Library, certain data on microfilm operations at other large university and research libraries were collected in July, 1954. Some of the data seemed of sufficient general interest to warrant their dissemination to a wider audience, which explains why this summary article was written.

\section{Production of Microfilm}

Information was obtained from all the $2 \mathrm{I}$ university libraries in the United States holding more than 900,000 volumes, as reported in the "Statistics for College and University Libraries, I952/53 (Princeton ),"' plus eight selected research, special, or public libraries that were known to own large research collections. ${ }^{2}$

\section{Patterns of Service}

All the 29 libraries made some kind of arrangements whereby library patrons could purchase microfilm copies of materials in their collections. However, only i 8 owned cameras, and only 14 of these did most of their own developing. Details are shown

I California (Berkeley), California (Los Angeles), Chicago, Columbia, Cornell, Duke, Harvard, Illinois, Indiana, Johns Hopkins, Michigan, Minnesota, New York University, Northwestern, Ohio State, Pennsylvania, Princeton, Stanford, Texas, Wisconsin, Yale.

2 Huntington, John Crerar, Linda Hall, Newberry, New York Public, U.S. Armed Forces Medical, U.S. Department of Agriculture, U.S. Library of Congress.
TABLE I

$35 \mathrm{~mm}$ Microfilming Equipment Owned by Research Libraries, July, I954

\begin{tabular}{lcl}
\hline \hline Libraries & $\begin{array}{c}\text { No. of } \\
\text { Cameras }\end{array}$ & $\begin{array}{c}\text { Developing } \\
\text { Done in } \\
\text { Library? }\end{array}$ \\
\hline $\begin{array}{l}\text { Library of Congress } \\
\text { U. S. Armed Forces Medical }\end{array}$ & $\begin{array}{l}24^{*} \\
\text { I6 }\end{array}$ & $\begin{array}{l}\text { yes } \\
\text { small } \\
\text { amounts }\end{array}$ \\
Chicago & 5 & yes \\
California (Berkeley) & 4 & yes \\
New York Public & 3 & yes \\
Yale & 3 & yes, except \\
& & for large \\
U. S. Dept. of Agriculture & 2 & yes \\
California (Los Angeles) & 2 & yes \\
Harvard & 2 & "some" \\
Huntington & 2 & yes \\
Linda Hall & 2 & yes \\
Princeton & 2 & yes \\
Columbia & I & yes \\
Duke & I & yes \\
Illinois & I & yes \\
John Crerar & I & no \\
Ohio State & I & no \\
Pennsylvania & I & yes
\end{tabular}

* Io Recordak Models E (portable), 9 Recordak Models D, 3 Recordak Models C-I, I Recordak Model C-2, I Diebold Flo-Film Model 0003 . The Library of Congress also owned 3 Remington Rand 16 mm cameras.

in Table I. Contrary to a statement in I950 that "all of the larger libraries have equipment for making microfilm," 3 it was found that among the 29 libraries surveyed, I I had neither microfilm camera equipment nor processing facilities of their own. Cornell, Johns Hopkins, Minnesota, New York University, and Stanford were having microfilming work done through campus

\footnotetext{
3 Vernon D. Tate, "An Appraisal of Microfilm," American Documentation, I (I950), 96.
} 
TABLE II

Production of Negative Microfilm By 2 I University and Research Libraries

\begin{tabular}{|c|c|c|}
\hline Library & $\begin{array}{l}\text { No. of } \\
\text { exposures }\end{array}$ & $\begin{array}{c}\text { Period } \\
\text { covered }\end{array}$ \\
\hline Library of Congress & $2,506,332$ & $1953 / 54$ \\
\hline New York Public & I $, 315,000$ & I $953 / 54$ \\
\hline $\begin{array}{l}\text { Chicago } \\
\text { U.S Armed Forces Medi- }\end{array}$ & 964,589 & $1952 / 53$ \\
\hline cal Library & 811,180 & 1953 \\
\hline California (Berkeley) & 572,652 & $1952 / 53$ \\
\hline Harvard & $420, \infty 00^{*}$ & I $953 / 54$ \\
\hline Linda Hall Library & $400, \infty 00$ & I 953 \\
\hline Michigan & 177,838 & I $953 / 54$ \\
\hline Yale & I 33,647 * & I $953 / 54$ \\
\hline Illinois & $100, \infty 0^{*}$ & I $953 / 54$ \\
\hline U. S. Dept. of Agriculture & $100, \infty 0^{*}$ & I $953 / 54$ \\
\hline Huntington Library & $1 \infty, \infty 0^{*}$ & average \\
\hline California (Los Angeles) & $99,200^{*}$ & $\begin{array}{l}\text { I } 944 / 54 \\
\text { I } 953 / 54\end{array}$ \\
\hline Columbia & $90, \infty 00$ & $1952 / 53$ \\
\hline Duke & $28, \infty 00$ & I $953 / 54$ \\
\hline Pennsylvania & 21,801 & I $953 / 54$ \\
\hline Princeton & 21,016 & I $953 / 54$ \\
\hline Stanford & $20, \infty 00$ & I953 \\
\hline John Crerar Library & 16,740 & I 953 \\
\hline Ohio State & $16, \infty 0^{*}$ & I953/54 \\
\hline Johns Hopkins & 6,350 & I $953 / 54$ \\
\hline
\end{tabular}

* Approximately.

photographic agencies. Michigan did its filming with a camera stationed in the library, but owned by the commercial firm University Microfilms. Northwestern referred requests for microfilming service to the University of Chicago. At Indiana, Texas, Wisconsin, and the Newberry Library, microfilming was handled through commercial concerns. Several of these libraries reported dissatisfaction with such arrangements, except where the volume of work was relatively small.

Table II shows the approximate annual output of major microfilming laboratories, exclusive of positive microfilm production. Although the data do not refer to precisely the same dates, they may be taken as indicative of the relative positions of the libraries with reference to their average production of negative microfilm. The total annual output may be estimated to be about $7,900,000$ exposures, of which the seven largest laboratories produced about $88 \%$.
The sales value of the total annual production of negative microfilm was approximately $\$ 300,000$ for the 2 I libraries involved.

\section{LABORATORY EQUIPMENT}

The camera equipment owned by the libraries most commonly consisted of Kodagraph Models D and/or C-I. Other cameras owned were a Kodagraph portable Model E, a Graflex Photorecord, a Diebold Flo-Film Model 9003, and, in one case, a Leica. $^{4}$

Developing equipment consisted either of continuous machine processing or manually operated flat reel systems, or both. ${ }^{5}$ One respondent wrote: "All you need for developing of films is $\$ 500$ (maximum) and a good-sized closet." 6 Those who have installed more expensive continuous machine processing equipment might dispute this recommendation and point to the risk of scratching the film with manually operated systems. As Fussler pointed out: "It is in this ever present risk of scratching, which occurs occasionally with even the most careful operator, that the principal disadvantage of the system lies."7

\section{Processing of Microfilm}

Those who rule out the manually operated flat reel systems, except for occasional emergency use, are faced with a choice between installing their own continuous machine processing equipment or having the developing of film done outside the library on a contractual basis. Libraries that have their film processing done commercially paid

\footnotetext{
4 For an early report on camera installations, see: Irvin Stewart, "Microphotographic Equipment in Certain Libraries," Journal of Documentary Reproduction, I (1938), 208-9.

s"Processing Methods for Microfilming," in Microfliming with Kodagraph Micro-File Equipment and Materials ("Kodak Industrial Handbook," published by the Eastman Kodak Company, I952), pp. 34:37.

See also: Richard C. Gremling, "You Can Afford Microphotography," Library Journal, LXXV (February I 5, 1950), 246-7.

Herman H. Fussler, Photographic Reproduction for Libraries (Chicago: University of Chicago Press, 1942), p. I 57 .
} 
between $\$ 6.03$ and $\$ 6.50$ for developing 100 feet of $35 \mathrm{~mm}$ film, including the cost of the film, or about $\$ \mathrm{I} .25$ if the cost of the film was not included. Among the laboratories that were engaged in developing work for libraries were the Recordak Corporation, the Graphic Microfilm Company, and University Microfilms, Inc.; all libraries reported that the work was satisfactory, except for distance and time delay in one case. In two instances, developing was done in the local photographic laboratory of the university (Stanford, Johns Hopkins). If we assume a minimum cost of $\$ 3000$ for continuous processing equipment (e.g., Diebold Model 9107) and an amortization period of 10 years, the annual cost of commercial processing would have to be, at least, $\$ 300$ before the investment in equipment could begin to pay for itself; to this amount must be added the cost of labor and chemicals, which would vary with the volume of processing. For $\$ 300,24,000$ feet of microfilm could be commercially processed.

One highly experienced respondent expressed the opinion that "IO to I 5 rolls of negative film per day can be handled quite economically by a commercial contractor." Another equally expert respondent, with whom this opinion was discussed, felt that machine processing equipment can be justified long before a volume of Io rolls a day is reached. No objēctive evidence is apparently available to suggest the point at which it may become economically advantageous to operate continuous machine processing equipment in a library as against having the developing work done by a commercial laboratory. The following calculations may be helpful : on the basis of 250 working days a year, Io rolls per working day amount to 2500 rolls per working year; if we assume 800 exposures per Ioo-foot roll at moderately low reduction, 2500 rolls will contain 2,000,000 exposures. Among the libraries surveyed, only the Library of Congress produced over 2,000,000 exposures of negative film per year. The production of positive film copies should, of course, be included in such considerations.

Among the 13 libraries producing between 100,000 and 2,500,000 exposures per year each, ten did their own processing; of these ten, only the Library of Congress, the University of Chicago, the University of California at Berkeley, and the University of California at Los Angeles used continuous machine processing. Of the remaining six libraries employing the flat reel system, all but two found it to be satisfactory. One library reported to have been "tempted to convert to continuous processing." The largest producer of negative microfilm using the flat reel system (Stineman) was the New York Public Library ( I,3 I 5,00o exposures). The two libraries that owned and operated cameras, but had all (or nearly all) their processing work farmed out to commercial laboratories, were Harvard and the U.S. Armed Forces Medical Library. Michigan was the only library producing over I00,000 exposures annually that owned neither a camera nor developing equipment. About 800,000 exposures per year (U.S. Armed Forces Medical Library) was apparently not too high a volume for handling by a commercial contractor. On the other hand, in one library producing about 400,000 exposures per year the staff considered their decision to do its own processing by means of Stineman reels a wise one because it enabled them to do work for themselves, and they felt that commercial agencies could not quickly handle the varying types of material for which their patrons requested microfilm. It usually is advantageous to develop film without delay near the location of the camera, so that retakes can be quickly produced before the documents are returned to the shelves or released for circulation. 
TABLE III

Rates for Microfilming Charged By 25 University and Research Libraries, I 954

\begin{tabular}{|c|c|c|c|c|c|c|c|}
\hline Library & $\begin{array}{l}\text { Rates } \\
\text { in } \\
\text { effect } \\
\text { since }\end{array}$ & $\begin{array}{l}\text { Bound } \\
\text { Vols. } \\
\text { Per } \\
\text { Expo- } \\
\text { sure } \\
\text { (First } \\
\text { IOO) }\end{array}$ & $\begin{array}{c}\text { Bound } \\
\text { Vols. } \\
\text { Per } \\
\text { Exposure } \\
\text { (over 1000) }\end{array}$ & $\begin{array}{l}\text { Manu- } \\
\text { scripts } \\
\text { Per } \\
\text { Expo- } \\
\text { sure }\end{array}$ & $\begin{array}{l}\text { Mini- } \\
\text { mum } \\
\text { per } \\
\text { Item } \\
\text { handled }\end{array}$ & $\begin{array}{c}\text { Vol- } \\
\text { ume } \\
\text { Charge, } \\
\text { size } \\
\text { change }\end{array}$ & $\begin{array}{l}\text { Mini- } \\
\text { mum } \\
\text { per } \\
\text { order }\end{array}$ \\
\hline California (Berkeley) & I952 & .035 & & .05 & & .15 & $1 . \infty$ \\
\hline California (Los Angeles) & I95 I & .035 & & .05 & & .15 & 1.00 \\
\hline Chicago & & .03 & & .05 & & .25 & $1 . \infty$ \\
\hline Columbia & I954 & .04 & & .05 & & .25 & $1 . \infty$ \\
\hline Duke & 1952 & .04 & & .05 & & .25 & $1 . \infty$ \\
\hline Harvard & I 946 & .035 & & & & & $1 . \infty$ \\
\hline Huntington Library & 1954 & .07 & & & & & I. 50 \\
\hline Illinois & 1949 & .03 & & & & .25 & I. $\infty$ \\
\hline John Crerar Library & I 95 I & .056 & & & & & I. 40 \\
\hline *Johns Hopkins & I 953 & .04 & & & & & $1 . \infty$ \\
\hline Linda Hall Library & I 848 & .03 & $.01(500+)$ & & & .50 & I. 25 \\
\hline **Michigan & 1948 & .035 & & & .50 & & 1.00 \\
\hline Minnesota & 1954 & .03 & $.02(500+)$ & & & & I. 50 \\
\hline New York Public Library & 1950 & .04 & $.03(1000+)$ & .05 & $1 . \infty$ & .25 & I. . \\
\hline *New York Library & 1948 & .05 & & & .75 & & .75 \\
\hline **Newberry Library & 1954 & .03 & & & .50 & .25 & .50 \\
\hline Ohio State & 1949 & .03 & & & & .25 & $1 . \infty$ \\
\hline Pennsylvania & 1947 & .04 & & & & & 1.00 \\
\hline Princeton & 1936 & .03 & & & & & \\
\hline *Stanford & 1952 & .035 & & .05 & & .15 & \\
\hline U. S. Dept. of Agriculture & I945 & $.04^{* * *}$ & & & & & $1 . \infty$ \\
\hline U. S. Armed Forces Medical & I 943 & .02 & & & .50 & & .50 \\
\hline U. S. Library of Congress & 1952 & .04 & $.03(1000+)$ & .05 & 1.00 & & 1.00 \\
\hline **Wisconsin & 1954 & $.08 * * * *$ & $.03(125+)$ & & 2.00 & & 2.00 \\
\hline Yale & 1952 & .04 & & & $1 . \infty$ & . 10 & 1.00 \\
\hline
\end{tabular}

* Microfilming rates established by non-library campus laboratory.

** Microfilming rates established by commercial laboratory.

$* * * \$ 1.00$ for each 50 pages or fraction thereof.

$* * * * \$ .04$ per page.

\section{Prices FOR MicrofiLM}

\section{VARIATIONS IN RATES}

The rates charged for microfilm varied from 24 to 7 per exposure, with a median of $3.5 \%$ and a mode of $4 \phi$. Rates varied in accordance with the type of material photographed and the length of individual items. Manuscripts or loose sheets cost $5 \phi$ per exposure. Quantity rates were quoted in 5 instances, the rates ranging from $1 \%$ to $3 \phi$ per exposure for minimum runs of 125,500 , or 1000 exposures, respectively. Practices varied with reference to charges per item handled, for volume and size changes, min- imum charges per order, charges for reels and boxes, and minimum charges for postage and mailing. Minimum charges per order were generally $\$$ I.OO or up. Selected details are shown in Table III.

The important question from the point of view of the consumer is how much microfilming will cost him. For instance, if he wishes to purchase 3 books of 600 pages each on microfilm, the prices may vary from $\$ 10.50$ to $\$ 47.50$, depending upon whether he orders the film from one library at the rate of I cent per exposure for runs of 500 and more plus $\$ .50$ for each volume handled, or whether he orders it from the com- 
mercial laboratory that handles microfilming for another library at the rate of 5 cents per exposure; the same order from a third library would cost about $\$ 39.15$ and from a fourth one, $\$ 28.50$. If we take as a second example an order of 10 articles in different journals, each about I4 pages long, involving a total of 70 exposures, the average (median) cost would be about $\$ 5.25$; but some libraries would charge as little as $\$ 3.00$ and 7 would charge $\$$ Io.oo or more. A consumer familiar with these variations can achieve savings if the document to be microfilmed is located in different libraries. ${ }^{8}$

\section{Cost Analysis}

The existence of such variations in rates raises the question as to the factors that should enter into the determination of rates. Two libraries admitted that their intention had merely been to keep their prices in line with those of similar institutions. Others looked upon microfilming as a service to research, justifying it on the same grounds as interlibrary loans, and did not expect to make income match expenses. A third group felt that microfilming service should be selfsustaining, but non-profit. The libraries claiming that their microfilm laboratories were self-sustaining were Linda $\mathrm{Hall}$ and the Library of Congress. At the University of Chicago, all expenses of the Department of Photographic Reproduction, except time spent by the general library staff in collecting and delivering the materials, were reported to be paid from current earnings. Among all the respondents, I I claimed that their prices took account of the time spent by the library staff in verifying and collecting the documents and bookkeeping; 13 reported that they did not consider such costs in determining their prices. In one case,

8 See also: (a) Esther M. Schlundt, "Services Available from Large Libraries," Special Libraries, XLV Services in the United States and Canada (rev. ed.; New York; Special Library Association, I947). university regulations apparently made it impossible to credit earnings to the library budget. The larger the operation, the greater the chances of placing microfilming services on a self-sustaining basis.

Precise matching of income with expenses is perhaps unnecessary if the production of microfilm is considered in the same class as library reference or circulation service, which are customarily given free of charge to the clientele of a library. One respondent representing a library that charged a relatively low rate expressed the following view: "We do not in any way attempt to correlate the salaries of the two operators with prices charged either for microfilm or photostat. The whole thing is looked upon as a service unit." It has also been argued that free microfilming service can be justified as a contribution to the advancement of knowledge. Seidell, the organizer of the microfilm service of the Armed Forces Medical Library stated: "If, as might be expected, the operation of a free microfilm service results in a very great increase in the amount of work a library is called upon to perform, this would simply be an evidence of the increasing use being made of the resources of that library and an indication that the library is fulfilling to a greater degree the purposes for which it exists. The additional funds to support such a meritorious extension of library activity should not be difficult to obtain."9 Actually no library has established completely free microfilming service, although the service provided by the Armed Forces Medical Library is a free service of a sort, since microfilm of materials not available locally is supplied free to those who return it within 90 days. To what extent such a quasi-free service is "exploited by minority of users," as Fussler feared, ${ }^{10}$ is not known.

9 Atherton Seidell, "The Cost of Microfilm Copying in Libraries," Journal of Documentary Reproduction, IV

(194I), 167. 
If a microfilming laboratory is to operate on a self-sustaining basis, the following factors would enter into the determination of rates: (I) Labor cost in camera work, developing, and inspecting of film; (2) supplies; (3) the cost of correspondence, packing, shipping, billing, accounting; and (4) equipment depreciation. Generally excluded from consideration in noncommercial operations are such overhead costs as space rental, building maintenance, water, heat, electricity, and telephone service. Controversial items are the cost of reference service (bibliographic identification and determination of call numbers) and circulation service (locating volumes on the shelves, transpcrting them to and from the laboratory). ${ }^{11}$

\section{Questions}

The survey was merely intended to supply a few descriptive data on existing microfilming services of large American university and research libraries. It was not intended to supply definitive answcrs to all questions that could be raised in connection with microfilming services. A useful purpose might be served if certain unanswered questions were briefly listed as an apyendix:

(I) Why do some of the large university and research libraries provide no services

11 For additional discussions of cost factors, $\sec$ (a) W. Janicki, "Cost Estimating and Cost Annlysis in Reproduction Work," Ferleration Internation-le de Doc. umentation (F.I.D.) Communications, XIIT. facs. umentation (F.I.D.) Communications. XIIT, facs. $3: \mathrm{C}_{30}-\mathrm{C}_{35}$; (b) Seidell, op. cit., pp. 164-167; (c) Fuss-
ler, op. cit., p. 60; (d) Ralph R. Shaw. "Bibliofilm Servler, op. cit., p. 6o; (d) Ralph R. Shaw "Bibliofilm Servof Documentary Reproduction, V (1942), 198-208. of their own? Should not all of them be expected to provide microfilming services?

(2) Why are libraries not exploiting the full production potential of their laboratories? What further cooperative measures could be taken to provide all existing laboratories with enough microfilm work to keep their machines and employees fully occupied on a continuing basis?

(3) Why do some libraries find the use of manually operated flat reel systems for developing of microfilm satisfactory and others not? Have techniques been developed in connection with the use of flat reel systems that are not known to all laboratory technicians?

(4) What are the advantages of having microfilm developed by a commercial laboratory as against having the developing done in the library's own laboratory by means of manually operated system?

(5) What volume of production is required before the use of continuous machine processing equipment for developing of microfilm can be recommended?

(6) How can the existing variations in prices charged for microfilm by libraries be explained? What factors should enter into the determination of prices? Why should laboratories attempt to operate on a self-sustaining basis?

(7) Should libraries not make a clear distinction between (a) the production of long runs for purposes of preservation and condensation and (b) the production of short runs as a current service comparable to circulation?

(8) Would libraries not find it advisable to reduce the prices for short runs of microfilm regardless of cost? How low must prices be before libraries can substitute microfilm for interlibrary loans in all cases?

\section{Conference Placement Service}

During the Philadelthia Conference, a simplified Contact Placement Clearing House will be available to employcrs and to librarians interested in changing positions. For dctails, see the May $A L A$ Bulletin, page 22?. 